\title{
A New Approach in Rural Development in Vietnam: Evaluation of the National Target Programme for Building New Rural Areas, 2011-2015
}

\section{SUMMARY}

This paper is a summary of the scientific research project entitled "Building New Rural Areas and Its Impacts on Sustainable Rural Development in Vietnam". Besides using a methodology based on quantitative and qualitative datasets, we gathered the literature review of rural development studies and practical frameworks of rural development programmes (RDPs). We made statistical analyses for the National Target Programme for Building New Rural Areas between 2011 and 2015 in Vietnam by an on-site empirical survey in a community in Vietnam. Our conclusion is that RDPs should specify the difficulties for each rural area in the process of decision-making for development planning, and should frequently classify difficulties during implementation for the decentralized administration of implementation from central offices to local authorities in order to set up priorities for each rural area.

Journal of Economic Literature (JEL) codes: O13, P21, Q18

Keywords: rural development, sustainability, commune, livelihood, quality of life, collective action, Vietnam, EU

\section{INTRODUCTION}

In their book entitled Dimensions of Need, published for the 50th anniversary of FAO (the Food and Agriculture Organisation of the United Nations), Loftas et al. (1995:3) pointed out that "the needs of the increasing population, poverty, malnutrition, land degradation, deforestation, pollution, loss

\footnotetext{
Nguyen Thi Thu Thuy PhD student, University of Kaposvár, Doctoral School for Management and Organisational Sciences (thuyszierwg@gmail.com); LÁszLó VASA senior researcher and chief advisor, Institute of Foreign Affairs and Trade, Budapest, research professor, Széchenyi István University (laszlo.vasa@ifat.hu).
} 


\section{Tudományos múhely}

of biological diversity and the overexploitation of the oceans remind us: there is no room for complacency". Therefore, FAO stated that "We must seek better and sustainable ways and means to meet and overcome these challenges and we must transform agriculture to combine increased productivity with sustainability of natural resources" (Loftas et al., 1995).

The 2016 Rural Development Report by IFAD added that "the world leaders have agreed on an ambitious development agenda that seeks to end poverty and hunger by 2030... Agenda 2030 has explicitly recognized the central role that rural development plays... Hence a transformation of rural areas is needed to enable rural people to capitalize on changes in the world around them, rather than be further marginalized by them" (IFAD, 2016:8).

Among these global circumstances, Vietnam was consistent and determined in its policy to develop the economy parallel with improving the social standard and protecting the environment. The country's constitution and its major national social and economic development strategies and plans envisage Vietnam as a modern and industrialised nation that will have become a prosperous, creative, equitable and democratic society by 2035 (World Bank - MPI of Vietnam, 2016).

\section{ObJECTIVES OF THE RESEARCH}

Rural areas and rural development have always played an important role in the economy and society in Vietnam. The Vietnamese government is seeking to build a powerful economy and sustainable development in order to improve the quality of life and ensure high living standards for the whole country, both in urban and rural areas. Increase in the inequality and disparity between the rich and the poor is a fact, and Vietnam is looking for ways to solve this problem. The subject of this study is to present the social, economic and environmental impacts of Building New Rural Areas in Vietnam and the link with rural development policies in order to synthesize conclusions for the sustainable rural development progress in Vietnam. The goal of this research is to improve understanding and facilitate the identification of solutions for genuine problems and opportunities to develop rural areas in Vietnam.

\section{HyPotheses}

In our study we suggest two hypotheses:

H1: There are positive impacts of the National Target Programme in Building New Rural Areas under sustainable rural development in economics, society and environment.

H2: There is a positive linkage between the National Target Programme in Building New Rural Areas and another national target programme in eradicating hunger and reducing poverty, promoting rural livelihoods in order to raise a living standard for rural population.

These hypotheses have been consolidated by the core background of theoretical and practical frameworks on rural development studies. Besides, the concept of rural livelihoods is a term that may be defined as follows: "A livelihood comprises the capabilities, assets (stores, resources, claims and access) and activities required for a means of living: a livelihood is sustainable which can cope with and recover from stress and shocks, maintain or enhance its capabilities and assets, and provide sustainable livelihood opportunities for the next generation; and which contributes net benefits to other livelihoods at the local and global levels, in the short and long term" (Krantz, 2001:1).

Going to capture impacts of measures to improve quality of life in rural areas is necessary for testing hypotheses. Thematic Working Group of the European Communities set the definition of Quality of Life for evaluation network of rural 


\section{Tudományos múhely}

development process such as: "The quality of life is a function of people's life circumstances, which of course have an economic dimension, but also includes their social networks, their health and their sense of worth, and the sustainably of the environment on which they depend. Quality of life emanates from having the capability to flourish." According to findings of the Thematic Working Group (Grieve et al., 2010), the quality of life implies a multidimensional character embracing social, environmental and economic dimensions. However, there is no simple and easy method to measure the quality of life" (Grieve et al., 2010:7).

\section{MATERIALS AND METHODS}

We used desk research, including scientific reviews about rural development, rural areas, rural studies and related disciplines and a source of secondary data in order to discuss the necessary issues. We applied scientific methods in social sciences specific to rural development study in order to identify the major factors of sustainable rural development that had been impacted by the National Target Programme in Building New Rural Areas in Vietnam.
As an important qualitative method, this paper contains a data analysis of the surveys in a small community in the Red River delta (Vietnam), an entity included in the National Target Programme in Building New Rural Areas in Vietnam between 2011 and 2015, in qualitative and quantitative data to deal with "a cluster of problems and phenomena".

\section{Literature review: concepts and reviews of approaches}

This is a synthesis of theories on rural development and their comparison to practical issues with the aim to promote sustainable rural development with special focus on Vietnam, through the National Target Programme in Building New Rural Areas between 2011 and 2015. The aim is to apply the theory to blueprint a survey in a community in the Red River delta under the National Target Programme in Building New Rural Areas between 2011 and 2015.

Another endeavour is to trigger collective action for rural development, while promoting the empowerment of rural communities in order to have effective outcomes. Details of the framework for collective action are set out below (Table 1).

Table 1: Framework for the theory of collective action in rural development studies

\begin{tabular}{l|l}
\hline Definitions & $\begin{array}{l}\text { Collective action as an "action taken by a group (either directly or on its } \\
\text { behalf through an organisation) in pursuit of members' perceived shared } \\
\text { interests" }\end{array}$ \\
\hline Types of collective action: according to the breakdown \\
\hline Cooperation & $\begin{array}{l}\text { bottom-up, farmer-to-farmer collective action } \\
\text { While some bottom-up collective actions may receive government support, } \\
\text { others may be carried out without government support }\end{array}$ \\
\hline Coordination & $\begin{array}{l}\text { top-down, agency-led collective action } \\
\text { Some top-down collective actions are promoted by government policies but } \\
\text { do not receive any support, while other collective actions receive support by } \\
\text { local and/or government }\end{array}$ \\
\hline
\end{tabular}

The role of collective action is increasingly analysed also in the context of agriculture and rural development.

Source: Vanni, 2014 


\section{Tudományos múhely}

Practical framework for studying rural development

The Vietnamese government's "Country report - 15 Years' of Achievement in the Vietnam Millennium Development Goals, 2015" stated that: "The country has concentrated on challenging goals and constructing national indicators based on three development pillars - the economy, the social and cultural sphere, and the environment" (Socialist Republic of Vietnam, 2015:43).

The current rural development policy in Vietnam

The management of agriculture and rural areas by the state can be interpreted at a macro-economic level (Oláh, 2014), and it is performed with the help of plans, strategies, programmes, projects and policies. Meanwhile policies of agricultural development and rural development play an important role indeed (Magda-Nyilas, 2013; Vásáry et al., 2013). However, rural development policy is not comprehensive in Vietnam at present. It needs to be implemented in co-operation with other National Target Programmes and national strategies under government management. McLeod Rivera et al. stated: "Even within the context of agriculture, no one strategy or programmatic approach will accomplish everything. The observation evidence is that agriculture is only one aspect of rural development and other elements need to be addressed" (McLeod Rivera-Qamar, 2003:25).

Obviously, agricultural development is increasingly improving sustainably and the welfare of nations (Kozák-Neszmélyi, 2020). Several countries in the world (especially less developed countries, but even developing countries) have large rural areas and a large ratio of rural residents with key activities in agriculture. Thus agricultural policy is in interaction with rural development policy regarding tasks and operations, and so it does not merely include plans for farming production but is also the way of improving new rural areas "with modern social and economic infrastructure; rational economic structure and production organisations...", improving the living standard (spiritual and physical life) of rural residents, and achieving sustainable development in rural areas" (OECD, 2015:117).

National Target Programme of Building New Rural Areas

Comparing the National Target Programme of Building New Rural Areas in Vietnam and the Rural Development Programme (RDP) in the EU we collected the objectives and operations.

1. RDP in Vietnam, 2011-2015

Objectives:

- In Vietnam agricultural policy is intertwined with rural development policy in tasks and operations. The objectives include building a developed and modern agriculture sector by improving new rural areas of "modern social and economic infrastructure; streamlined economic structure and production organisations, improving the standard of living for rural residents, and achieving sustainable development."

- The aim of the National Target Programme for New Rural Development in Vietnam is to bring farmers in focus. They act as the managers and inspectors in implementing projects, and participate in the process of Building New Rural Areas to avoid overlaps and damage to the current rural property.

Operations:

- The National Target Programme of Building New Rural Areas between 2010 and 2020, with an outlook to 2030, was worked out by the government in order to build new rural areas in Vietnam. The first stage was implemented between 2011 and 2015 and covered the entire country according to national criteria.

- The Ministry of Agriculture and Rural development is the host and co-ordinates offices, agencies, people's committees and 


\section{Tudományos múhely}

provinces, drafts legal documents and sets up training staff for building new rural areas.

\section{RDPs in the $E U, 2007-2013$}

Objectives:

- RD policy has adapted and evolved since its inception in order to reflect key EU priorities. Rural development policy has enabled many farmers to learn new techniques, upgrade facilities and carry out essential restructuring, thus sharpening their competitive edge.

- Farming and forestry remain crucial for the management of natural resources in the EU's rural areas as well as a platform for economic diversification in rural communities.

- The sustainable development of rural areas has been a key objective of the EU's Common Agricultural Policy since it was formally established as the second pillar of the policy in 2000, with increasingly important budget allocations.

Operations:

- Support to RD between 2007 and 2013 included supporting structural adjustment in agriculture to better reflecting the multiple role of farming in the wider rural context. Policy put a greater emphasis on implementing a coherent strategy for rural development across the EU. The EU's contribution to financing measures depends on the measure and the region concerned.

- Since 2013, in the EU it is implemented through a single fund, in a single management and control system and a single type of programming (Borec-Turk, 2009:42; OECD, 2015:117; European Commission, 2000; 2005; 2008).

\section{Primary research: survey}

The survey was planned in a holistic approach: selected cases reflect the characteristics and problems of the theoretical propositions described in the literature review. In the frame of the survey in the topic "Finding some factors of endogenous capacity to building new sustainable rural areas in between 2011 and 2015 in Hong Lac commune, Thanh Ha district, Hai Duong province, Vietnam," questions were asked and responses given in two questionnaires.

Based on the SWOT analysis, the survey collects cases in a community to describe a top-down and a bottom-up scheme in the Building New Rural Areas project, in the Hong Lac community under the National Target Programme. The aim of the survey was to identify internal advantages and endogenous development in a small community in the Red River delta in Vietnam.

\section{FINDINGS AND DISCUSSION}

Results of the Building New Rural Areas in Vietnam, 2011-2015 Project, based on the Rural, Agricultural, and Fishery Census, 2016

The National Target Programme for Building New Rural Areas is being implemented in rural areas nationwide between 2010 and 2020. By 2020, 50 per cent of the communities will have reached the standard of new rural areas (according to the national criteria). The first stage of the National Target Programme for Building New Rural Areas between 2011 and 2015 was devoted to making decisions on agricultural and rural development in Vietnam in the frame of the "Agricultural policy objectives: current in Vietnam", which established that: "The overall goals for agricultural policy as set out in the MARD plan for the five years between 2011 and 2015 are to achieve sustainable development with high quality output; improve the living standard of people living in rural areas, especially the poor; and protect and effectively utilise natural resources and the environment" (OECD, 2015:113).

Therefore, in the first stage (2011-2015) of the National Target Programme for Building New Rural Areas between 2010 and 2020, the triangle model of agriculture was in focus, including the re-orientation of farmers and rural areas for agricultural and rural development in Vietnam. In order to implement the National Target Programme 


\section{Tudományos múhely}

for Building New Rural Areas in Vietnam, the government diversified the capital that was mobilized for the programme according to the action plan shown Figure 1.

There are 19 national criteria for building new dynamic rural areas in Vietnam between 2010 and 2020, with an outlook to 2030. They are divided into five specific categories: programming, social and economic infrastructure, economics and production, and a complex cultural, social, environment and political system.

Vietnam's economy has been in transition from an agriculture-based economy since the 1986 "Renewal" (Doi Moi Progress), targeting complete social and economic development.

A 2015 report of Vietnam described the following characteristics: "Challenges for Viet- nam's economic growth: Low-value added and labour-intensive activities predominate, ties between foreign investments and domestic enterprises remain weak and there is limited technology transfer... These, alongside pressures towards greater inequality, will intensify as Vietnam develops further to a middle-income country.

Opportunities for sustainable development: Vietnam needs to upgrade its labour productivity through a focus on developing the skills of its workforce, maintaining macroeconomic and political stability, reforming governance to promote a more efficient and transparent system, promoting the development of science and the adoption of new technologies, and to build a world-class infrastructure" (Socialist Republic of Vietnam, 2015:21, 131-132).

Figure 1: Financial mobilisation scheme to implement the National Target Programme for Building New Rural Areas in Vietnam (2011-2015)

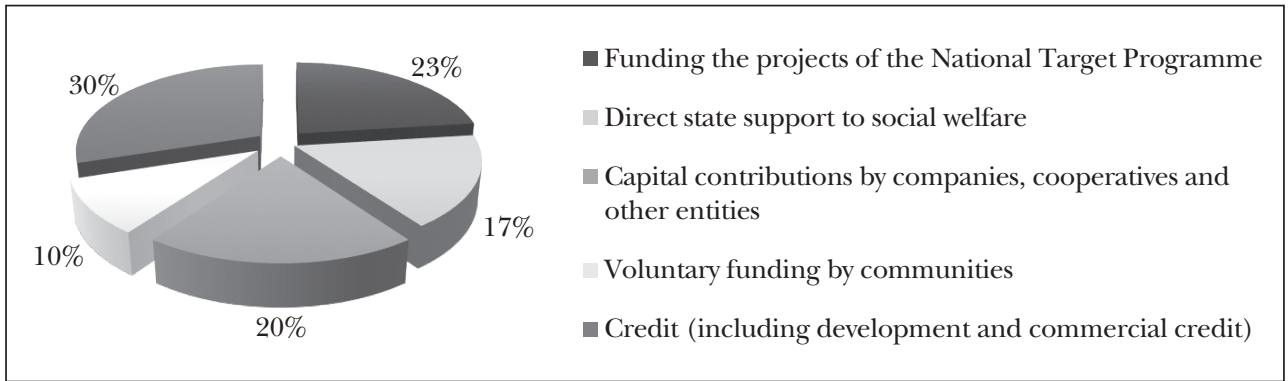

Source: Prime Minister of Socialist Republic of Vietnam, 2010

Figure 2: National accounts, Vietnam (2010-2017)

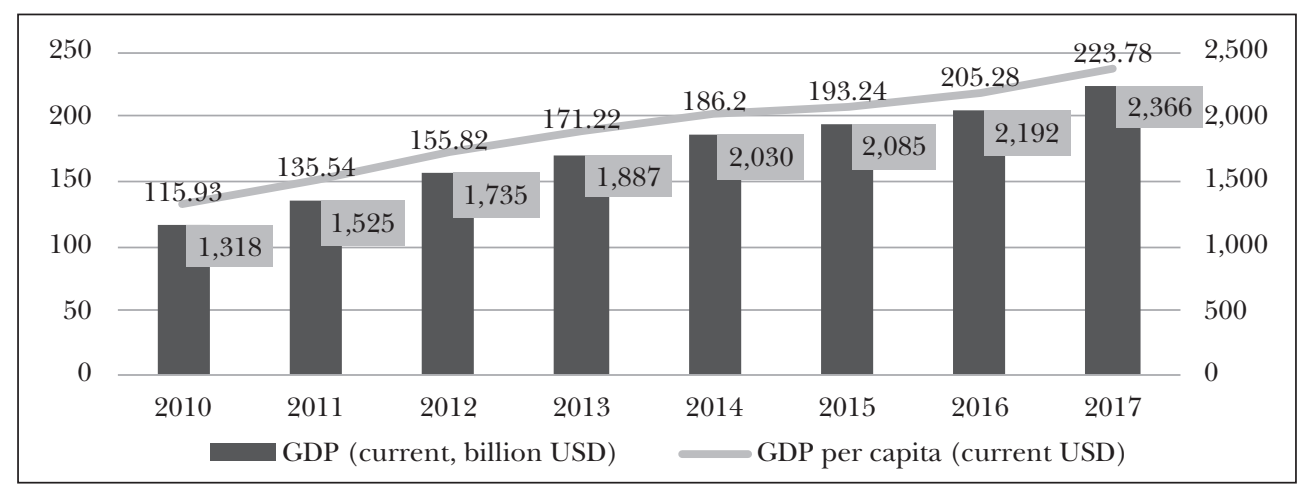

Source: World Bank, World Development Indicators database; GSO, 2018 


\section{Tudományos múhely}

Evaluation of the Rural, Agricultural and Fishery Census, 2016

The results of the National Target Programme for Building New Rural Areas in Vietnam between 2011 and 2015 illustrated by the GSO data of the Rural, Agricultural and Fishery Census, 2016 (hereafter: National Agri Census) correspond to the findings of our research. According to the findings of the Census, on 1 July 2016, the Vietnamese rural areas consisted of 8978 communities and 79,898 villages; 93 communities and 1006 villages less than on 1 July 2011. Decrease in those five years was mainly due to urbanisation, and to the fact that some rural areas had been split and recognized as urban areas (GSO, 2018:57).

Within five years (2011-2016), all the sectors and levels (from the central to the local level) did effectively implement many rural social and economic development measures and policies. There had been profound changes in the rural landscape, particularly in terms of investment in infrastructure construction (GSO, 2018).

Achievements on 1 July 2016 according to the Census of the National Target Programme in Building New Rural Areas 2011-2015) are the following:

Figure 3: Communes in the national census, 2016

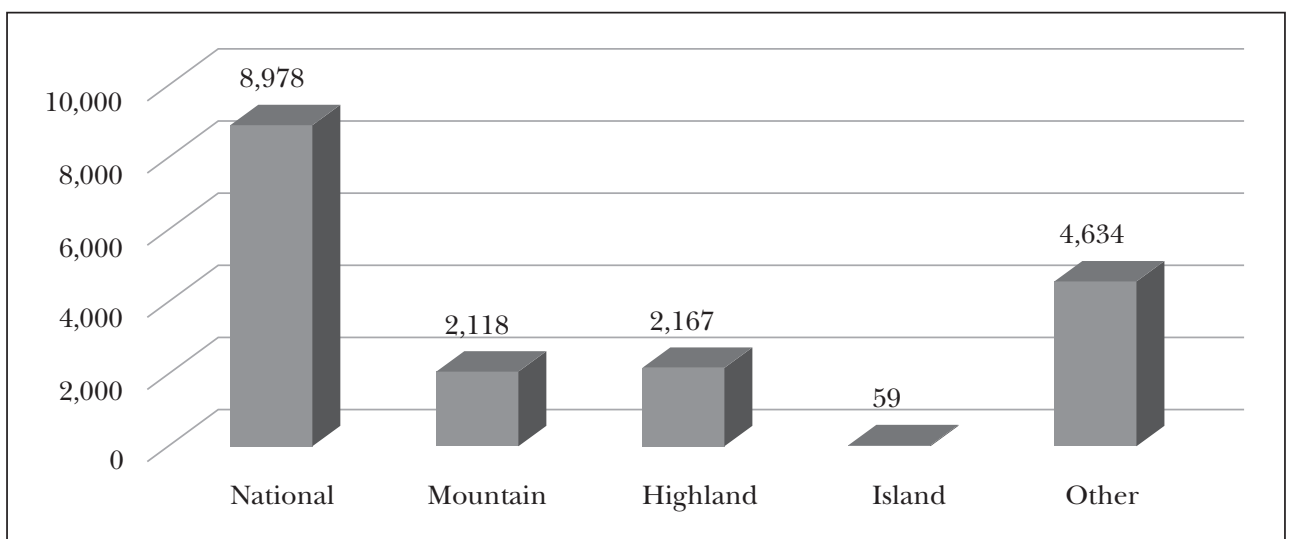

Source: GSO, 2018

Figure 4: Living conditions of rural households by type of commune

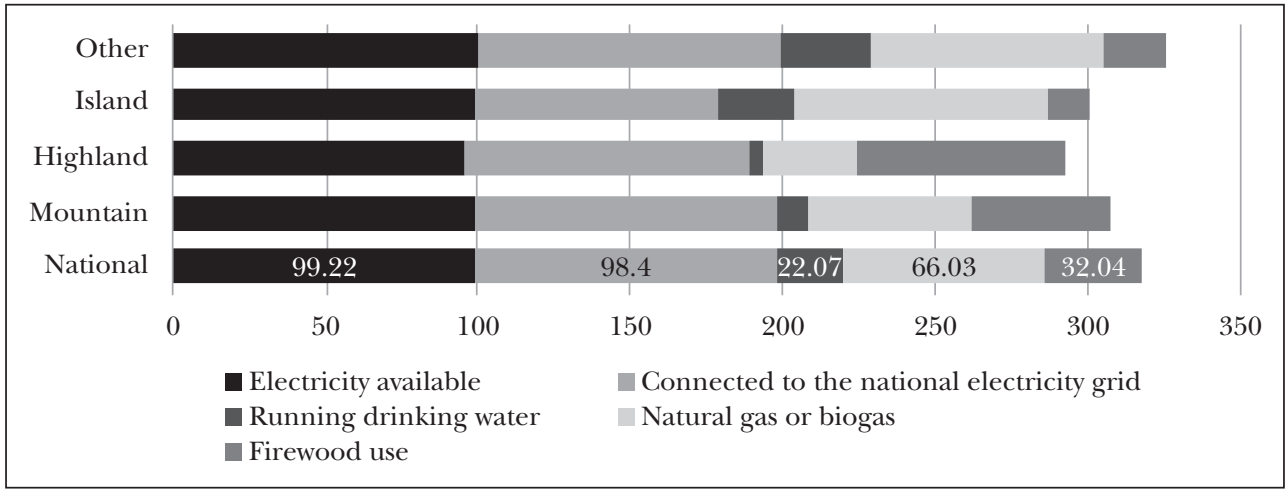

Source: GSO, 2018 


\section{Tudományos múhely}

- Roughly 5.06 million rural households were supplied with water from the central water works; only 1.9 per cent rural households still rely on rivers, lakes or ponds for water supply.

- The average number of doctors in community health stations (CHS) per 10,000 people increased from 1.12 in 2011 to more than 1.37 in 2016 . The coverage of health insurance in 2016 was 76.4 per cent of the total rural population, nearly equal to 1.4 times that of 2011.

- As much as 53.6 per cent of the households participated in activities at community halls of villages or larger communities; and 49.9 per cent of the households maintained regular participation.

- In 2016, 66.6 per cent of rural households used industrial gas, bio-gas, or electricity for cooking. The ratio of households using coal and firewood was 33.1 per cent in 2016;

- A total of 75.6 per cent rural households used built bathrooms; and the ratio of rural households using flush toilets and semi-flush toilets was 64.5 per cent (GSO, 2018).

The achievements of the National Target Programme for Building New Rural Areas between 2011 and 2015 in Vietnam provide a positive picture for rural areas as a result of rural residents' volunteer participation and due to the massive involvement of the staff, especially to the contribution of the excellent management by community leaders in whole country.

In addition, the positive impacts of the achievements of the National Target Programme for Building New Rural Areas had an overall impact on rural economy with some major changes mentioned below.

- The first impact is the restructuring of production by diversification.

- The second impact is focus on the application of science and technology.

- The third impact is the mechanisation of production that had been strengthened.
Shortcomings in the National Target

Programme for Building New Rural Areas between 2011 and 2015, according to the 2016 census

The shortcomings of the National Target Programme for Building New Rural Areas were not only reflected in the number of communities which had not accomplished all the criteria, but also in the number of communities that made efforts at hitting the standards but failing to fully satisfy the criteria. However, by 2016, 1304 communities had achieved 15-19 criteria, accounting for 19.0 per cent of the total number of communities which made efforts at obtaining the new-style rural status; and 3101 communities had achieved 10-14 criteria, accounting for 45.3 per cent. On the average of all the involved communities, each community had reached 10.9 criteria (GSO, 2018).

Finally, the conclusion for the Rural, Agricultural and Fishery Census, 2016 was that besides the successes, the rural social and economic situation and agricultural, forestry, and fishery production had many constraints and weaknesses. The economic structure was transiting slowly, and smallscale production was still common. Investment in rural areas and agriculture was limited. The labour force was large but qualifications and skills were low. A part of the rural population inhabiting the mountains, highlands and remote areas were facing increased difficulties and inadequacy (GSO 2018).

Findings of a Survey in the Hong Lac community, Hai Duong province, Vietnam related to the National Target Programme for Building New Rural Areas in Vietnam, 2011-2015

A report of the survey describes the progress of the Hong Lac community from the time it joined the National Target Programme for Building New Rural Areas in Vietnam in order to reduce poverty and build a sustain- 


\section{Tudományos múhely}

able rural area. The report discusses all the achievements in improving the quality of life and sustainable rural livelihoods for rural residents, but also identifies challenges in this programme for the community.

The report sets a frame/scenario based on the phenomena identified by data collection performed twice in 2014 and in 2017 in the Hong Lac community in order to measure the achievement of the research goals.

Preparing a plan for Building New Rural

Areas in the Hong Lac community

The Hong Lac community is located in the Thanh Ha district, Hai Duong province in the social and economic region of the Red River delta in Vietnam.

The community occupies a total area of 852.9 ha $\left(8.53 \mathrm{~km}^{2}\right.$, of which 543.4 ha of land is used for agriculture and 309.5ha for non-agricultural activities). The rural population has increased from 9.1 thousand people (living in 2474 households) in 2010 to 10.3 thousand people (3213 households) in 2017.

Facts of the implementation of the National Target Programme for Building New Rural Areas between 2011-2015 in the Hong Lac community

Both the top-down approach, i.e. delivering the policies from a centre to the local units, and the bottom-up approach, operated by feedback from the rural residents, have been used, while the community leaders and rural residents have both been stakeholders in implementing the objectives of the programme aimed at improving the standard of living and creating sustainable local areas.

The above charts demonstrate the potentials and advantages of community in agricultural production. The achievements have improved the standard of living, promoted the alteration of the labour structure and transition from agricultural to non-agricultural jobs, and increased food security in the community. As these impacts achieved during the implementation of the programme (between 2011 and 2015) in sustainable rural development proved to be favourable for the Hong Lac community, the programme was extended first to December 2017 and then again to subsequent dates.

First survey, August 2014: All the responses showed significant improvement in the awareness of rural residents in the Hong Lac community of the National Target Programme. The rural population is highly interested in the programme, as it had made a genuine change in their conditions and had promoted sustainable development for the community.

Second survey, November 2017: All the responses provided by the rural residents in the second survey gave positive feedback and realistic recommendations for the programme in the community. This suggests that all the rural residents had played a role as core stakeholders in this programme (in addition to being aware of the policies, they proactively contributed) and they all welcomed the positive changes in the community, as all the dimensions of society, economics and environment (three pillars of sustainable development) had improved and resulted in a higher standard of life, and they are now capable of finding more sustainable livelihoods (mainly job opportunities) within their communities.

\section{CONCLUSIONS FOR SUSTAINABLE}

RURAL DEVELOPMENT BASED ON THE SURVEY CONDUCTED IN THE HoNG LAC Community

According to the argumentation of McLeod Rivera and Qamar investing in agricultural development and in rural development is the sustainable solution for reducing poverty and improving the living standard for rural residents (McLeod Rivera-Qamar, 2003:19). 


\section{Tudományos múhely}

Figure 5: Economic structure in the Hong Lac community, 2010-2016

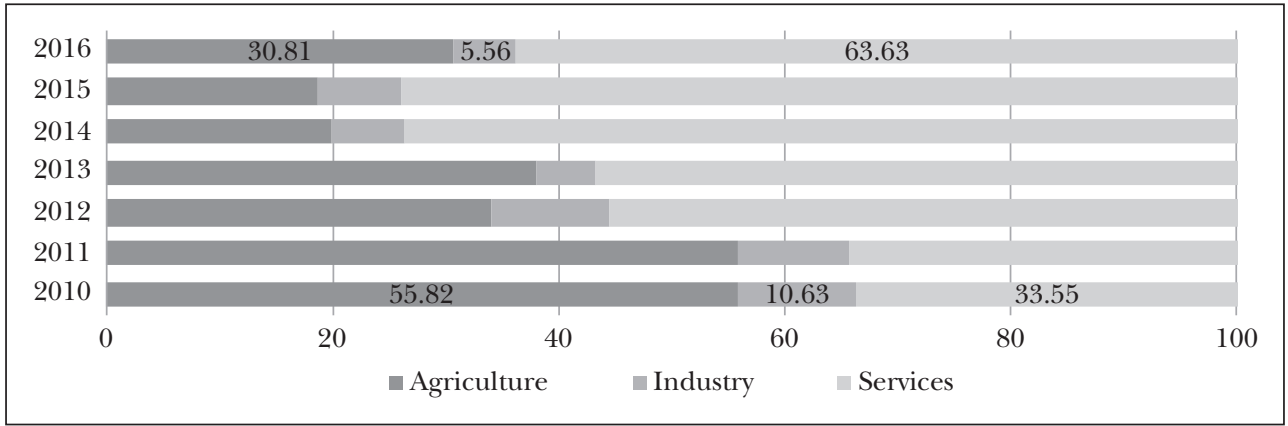

Note: Surveys in 2014 and 2017

Source: By the author

Figure 6: Population and basic living standards in the Hong Lac community

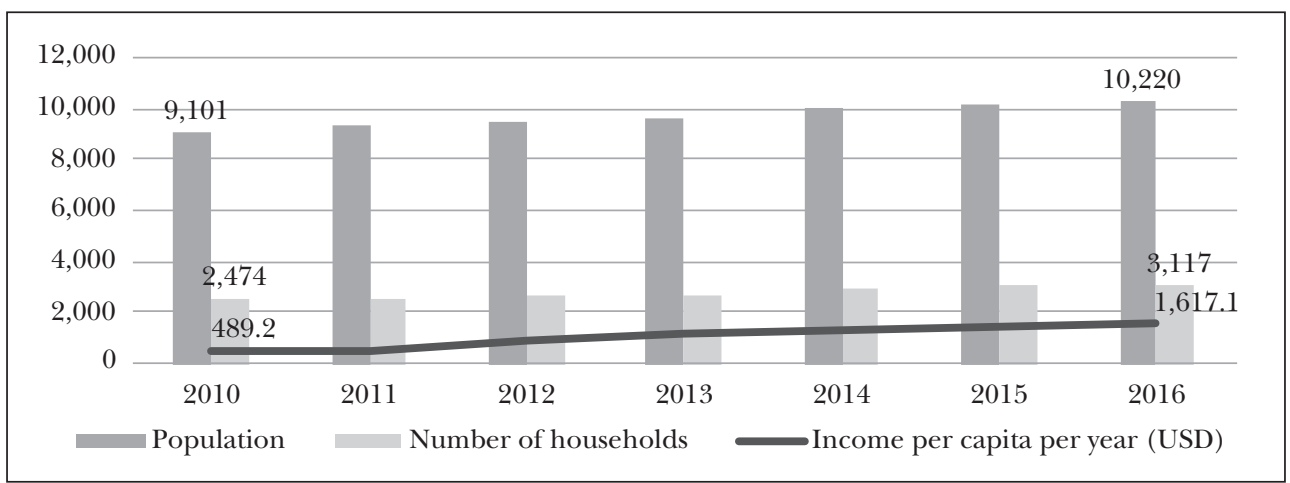

Note: Surveys in 2014 and 2017

Source: By the author

Figure 7: Rural residents' living conditions in the Hong Lac community

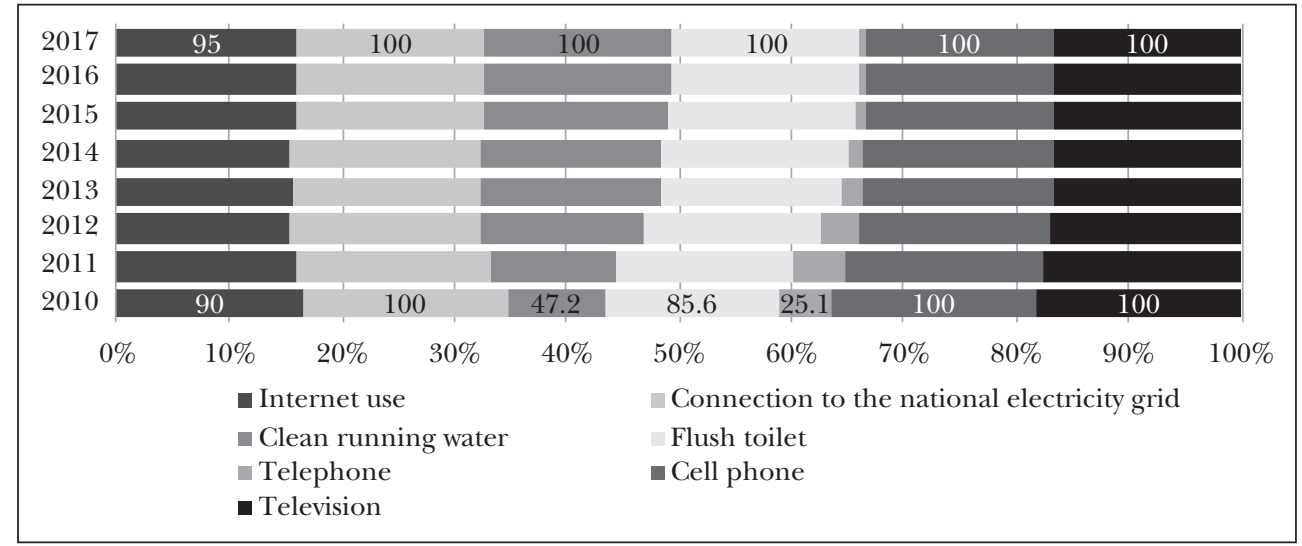

Note: Surveys in 2014 and 2017

Source: By the author 


\section{Tudományos múhely}

These reviews reveal various lessons on the implementation of the National Target Programme for Building New Rural Areas in the Hong Lac community at the time of its completion in December 2017.

(1) The way out of poverty, backlog and food insecurity: the community has tried to find a pathway out of poverty and it needs to be accredited after year 2017 by having more rural livelihoods - create more jobs and improve income generation for rural residents including poor households. This need should not depend solely on the agricultural output of the community but also on job opportunities in rural industry and rural service.

(2) The two surveys received important feedbacks from interviewees, which are useful inputs about the role of stakeholders in this programme. The conclusions confirm that the RD policies are important for rural transition and for revival in the community in social, economic and environmental terms, but rural residents are always the stakeholders who decide the success or failure of this programme. The objectives of the National Target Programme are positive and beneficial for them, but only rural residents can create the change for their communities. The local authorities or community leaders are accompanying actors in this process.

The National Target Programme for Building New Rural Areas in Vietnam between 2011 and 2015 faces many difficulties and challenges for sustainable development in rural areas. But the most important outcome of this programme is that it has managed to build a rural infrastructure meeting the national criteria to redress social, economic and environmental problems in rural areas. This is a tangible favourable achievement to share, and the Hong Lac community is a good proof for scientific research.

Nonetheless, the European Union has revised the agricultural sector in all aspects and found that economic and environ- mental sustainability, adequate farmer incomes, productive capacity for the future, improved food security and social sustainability are important elements in developing countries' agricultural development.

Based on the significant analyses, we recommend that in the second stage of Vietnam's National Target Programme for Building New Rural Areas (2016-2020) and over the long term, rural development policy should capitalise on the lessons learnt from the above overview in order to have even more positive impacts on rural living.

\section{Policy proposals for Building New \\ Rural Areas in Vietnam}

Decision making is fundamentally important for the management and organisation of governments during both the announcement and the critical evaluation of policies.

In the framework of the Building New Rural Areas programme, in addition to building roads and sewage networks, irrigation channels, schools, and community halls, farmers and rural residents are also provided the opportunity to identify with the objectives of the programme, take a proactive part in a confident, independent, decisive and creative way in rapidly developing and sustainable rural areas. Farmers and rural residents should be involved as stakeholders to raise the standard of their own life. It is an empowerment process for rural residents in their communities.

In our opinion, the staff at the centres and at localities (community leaders and workers) should be clustered to help rural residents recognize the importance of the Building New Rural Areas through a communication system (rural media). A flexible organisation should be set up in rural production (or farming), including cooperatives and collective units, to capture local specificities and to explore the endogenous capability under the current conditions of decentralisation and globalisation. In our opinion, governments need to verify or- 


\section{Tudományos múhely}

ganisational tasks of agricultural and rural development policies. These tasks require dialogue and cooperation to call for new attitudes and skills.

On the other hand, at the level of decision-making, it is necessary to consider the long-term objectives for the plan of restructuring the agricultural sector in Vietnam towards increasing added value in the value chain and in sustainable development. Therefore, we recommend that this sector should shift from the top-down approach by government policies to interaction by considering a bottom-up approach using rural residents' feedback during the transition. For this reason all the objectives (of the Rural Agricultural Plan) should link to sustainable rural development, and agriculture and rural development should be coherently interrelated.

\section{REFERENCES}

Borec, Andreja - Turk, Jernej (2009): Sustainable Rural Development - EU Agricultural Perspective. Revija za geografijo/Journal for Geography, Vol. 4, No. 1, 37-52.

Dung, N. M. - Thuy, V. T. P. - Song N. V. (2010): Textbook of Environmental Economics (Giáo trình Kinh tế Môi truoòng). Hanoi University of Agriculture.

European Communities (2008): The Aid Delivery Methods Programme, 2008. Reference Document No. 5, Sector Approaches in Agriculture and Rural Development, 5, 8-9.

European Commission (2000): Previous Rural Development Programming Periods. https://ec.europa. eu/info/food-farming-fisheries/key-policies/ common-agricultural-policy/rural-development/previous-rdp-periods.

European Commission (2005): National and Regional Programmes. https://enrd.ec.europa. eu/enrd-static/policy-in-action/rural-development-policy-overview/national-and-regionalprogrammes/en/national-and-regional-programmes_en.html.

European Commission (2008): EU Rural Development Policy 2007-2013. https://enrd.ec.europa. eu/enrd-static/fms/pdf/BEC22A59-E570-413B5A9B-682D3306E183.pdf.
European Commission (2011): Agricultural Policy Perspectives Briefs No. 4. The Future of Rural Development Policy. European Commission, https:// ec.europa.eu/info/sites/info/files/food-farming-fisheries/farming/documents/agri-policyperspectives-brief-04_en.pdf.

Grieve, John et al. (2010): Working Paper on Capturing Impacts of Leader and of Measures to Improve Quality of Life in Rural Areas. European Commission, http://ec.europa.eu/agriculture/rurdev/ eval/wp-leader_en.pdf.

GSO (2018): Results of the Rural, Agricultural and Fishery Census 2016. General Statistics Office of Vietnam, Hanoi, 84-87, 89-90, 110.

IFAD (2016): Rural Development Report 2016. Fostering Inclusive Rural Transformation. International Fund for Agricultural Development.

Kozák, Tamás - Neszmélyi, György (2020): The Regional Influence of Agriculture on Rural Economy. Romanian Review of Regional Studies, Vol. 15, No. 2, 19-28.

Krantz, Lasse (2001): The Sustainable Livelihood Approach to Poverty Reduction. An Introduction. Swedish International Development Cooperation Agency.

Loftas, Tony (ed.) (1995): Dimensions of Need. An Atlas of Food and Agriculture. Food and Agriculture Organisation of the United Nations, Rome.

Magda, Róbert - Nyilas, Ilona (2013): Role of the Natural and Human Resources in Rural Development. Verejná Sprava a Regionálny Rozvoj, Vol. 9, No. 2, 123-132.

McLeod Rivera, William - Qamar, M. Kalim (2003): Agricultural Extension, Rural Development and the Food Security Challenge. Food and Agriculture Organisation of the United Nations, Sustainable Development Department, Rome.

Oakley, P. - Garforth, C. (1985): Guide to Extension Training. Food and Agriculture Organisation of the United Nations (FAO), Rome.

OECD (2001): Policy Brief. Sustainable Development Strategies. What Are They and How Can Development Co-Operation Agencies Support Them? OECD Observer.

OECD (2015): Agricultural Policies in Viet Nam 2015. OECD.

Oláh, Judit (2014): The Problem of the Typologisation of Rural Regions in Europe. Euroregional Journal of Socio-Economic Analysis, Vol. 2, No. 1, 17-28.

Prime Minister of Socialist Republic of Vietnam (2010): Decision No. 800/QD-TTg Approving the 


\section{Tudományos múhely}

National Target Program on Building a New Countryside During 2010-2020. 4 June, Hanoi.

Skuras, Dimitris - Stathopoulou, Sophia - Psaltopoulos, Demetrios (1998): Rural Entrepreneurship in Europe - A Research Framework and Agenda. International Journal of Entrepreneurial Behaviour E Research, Vol. 10, No. 6, 404-425, https://doi.org/10.1108/13552550410564725.

Socialist Republic of Vietnam (2015): Country Report. 15 Years Achieving the Vietnam Millennium Development Goals. Socialist Republic of Vietnam, Ministry of Planning and Investment.

Thang, V. D. - Dinh, H. V. (2002): Textbook "Rural Development Economics". "Giáo trình Kinh tế phát triển nông thôn”. National Economics University, Chapter 1 and 2.
Van der Ploeg, Jan D. et al. (2000): Rural Development: From Practices and Policies towards Theory, Sociological Ruralis, Vol. 40, No. 4, 391-408, https://doi.org/10.1111/1467-9523.00156.

Vanni, Francesco (2014): Agriculture and Public Goods. Springer Netherlands.

Vásáry, Miklós - Vasa, László - Baranyai, Zsolt (2013): Analysing Competitiveness in Agrotrade among Visegrad Countries. Actual Problems of Economics, Vol. 150, No. 12, 134-145.

World Bank - MPI of Vietnam (2016): Vietnam 2035: Toward Prosperity, Creativity, Equity, and Democracy. World Bank, Washington, DC, https:/ / openknowledge.worldbank.org/handle/10986/23724. 